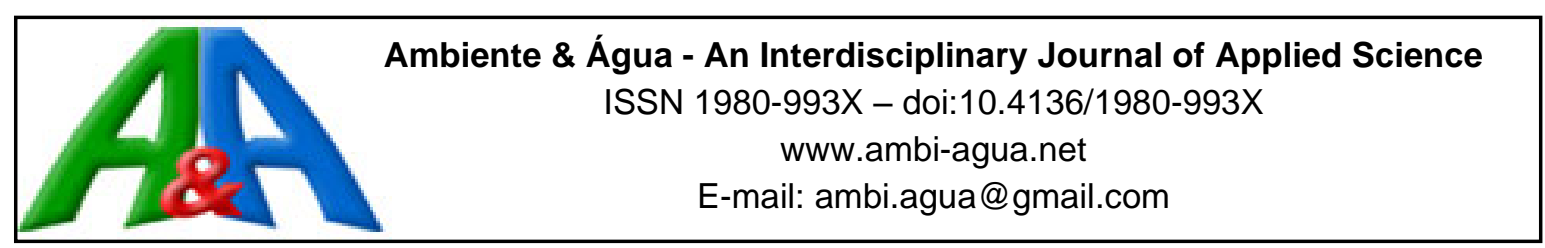

\title{
A digital game about water use as a teaching-learning tool in elementary school
}

\author{
ARTICLES doi:10.4136/ambi-agua.2562
}

Received: 05 Oct. 2020; Accepted: 09 Nov. 2020

\author{
Julien César Mélega ${ }^{(D)}$ Marcelo dos Santos Targa* \\ Programa de Pós-Graduação em Ciências Ambientais (PPGCA). Universidade de Taubaté (UNITAU), \\ Estrada Municipal Dr. José Luiz Cembranelli, n5000, CEP: 12081-010, Taubaté, SP, Brazil. \\ E-mail: melegajulien@gmail.com \\ *Corresponding author. E-mail: targa.marcelo@gmail.com
}

\begin{abstract}
With the emergence of Information and Communication Technologies (ICTs), there was also the development of specific technologies applied to Environmental Education which are used by teachers. In this context, several softwares for teaching/learning were developed, with educational games aiming at stimulating student's knowledge skills using amusement among the available modalities. In Brazil, several digital games have been created to meet the demands set out in the National Water Resources Policies (Law 9433/97) and Environmental Education (Law 9795/99), which states in its Article 2 that Environmental Education must be present at all levels of education. The present study characterized the profile of students of Elementary School II on the issue of water and verified the satisfaction of the digital game on the part of the students, identifying suggestions and ideas as to the benefits that the practice of digital gaming can offer in the classroom and in teaching practice. The study was developed in a school unit, part of the education network of Taubaté municipality, SP, and carried out with 63 eighthgrade students, with ages varying from 13 to 14 years, using the digital game Educa-AçãoÁgua. The first activity in this study was to raise students' awareness through a visit to the municipality's water capture and treatment station. In the data collection phase, a first questionnaire was applied in order to determine the students' level of knowledge on the topic of water and, later, after the students played the digital game, they answered a second questionnaire. The activity with the digital game Educa-Ação-Água led to students' awareness and learning about the water theme, leading them to recognize its importance and developing critical sense. In an evaluation of the game, it was observed that $51.6 \%$ of the students rated the game as "Good" and 35\% of them rated it as "Very Good", $88 \%$ felt encouraged to finish the game (Save the Tijuco River) and about $65 \%$ would play again at home or in the classroom. There was a contribution from students (players) when evaluating the game Educa-Ação-Água, noting points to be improved. The use of the WordCloud Tool allowed for a satisfactory graphical visualization of the students' answers.
\end{abstract}

Keywords: environmental awareness, environmental perception, environmental sciences, game, water. 


\section{Um jogo digital sobre o uso da água como ferramenta de ensino- aprendizagem na escola de educação básica}

\section{RESUMO}

Com o surgimento das Tecnologias da Informação e Comunicação (TIC's), desenvolveram-se também, aquelas aplicadas à Educação Ambiental, que são utilizadas por professores em atividades de ensino e aprendizagem. Nesse contexto, foram desenvolvidos vários softwares para o ensino-aprendizagem, sendo os jogos educacionais, cujo objetivo é estimular as habilidades do conhecimento do aluno utilizando o lúdico, uma das modalidades disponíveis. No Brasil vários jogos digitais têm sido criados para atender as demandas previstas (Lei n 9.433 de 1997) e de Educação Ambiental (Lei no 9.795/99), a qual define em seu artigo $2^{\circ}$ que a Educação Ambiental deve estar presente em todos os níveis da educação. O presente estudo teve como objetivos caracterizar o perfil de alunos do oitavo ano do Ensino Fundamental II sobre a questão da água e verificar a satisfação do jogo digital por parte dos alunos, identificando sugestões e ideias quanto aos benefícios que a prática de jogo digital pode oferecer em sala de aula e na prática docente. $O$ presente estudo foi desenvolvido em uma unidade escolar, da rede de educação do município de Taubaté, SP e foi realizada com 63 alunos do oitavo ano, com idade variando de 13 a 14 anos, por meio da utilização do jogo digital Educa-Ação-Água. A primeira atividade nesse estudo, foi realizar a sensibilização dos alunos, por meio de uma visita à Estação de captação e tratamento de água do município. Na coleta de dados aplicou-se um primeiro questionário com o objetivo de apurar o nível de conhecimento dos alunos sobre o tema água e, posteriormente, após os alunos jogarem o jogo digital eles responderam um segundo questionário. A atividade com o jogo digital Educa-Ação-Água levou à sensibilização e ao aprendizado dos alunos sobre o tema água, fazendo-os reconhecer sua importância e desenvolvendo o senso crítico. Na avaliação do jogo observou-se que 51,6\% dos alunos classificaram o jogo como "Bom" e 35\% deles classificaram como "Muito Bom", $88 \%$ se sentiram estimulados a terminar o jogo (Salvar o rio Tijuco) e cerca de $65 \%$ jogariam novamente em casa ou em sala de aula. Houve contribuição dos alunos (jogadores) ao avaliar o jogo Educa-Ação-Água, apontando pontos a serem melhorados. O uso da Ferramenta WordCloud permitiu de modo satisfatório a visualização gráfica das respostas dos alunos.

Palavras-chave: água, ciências ambientais, consciência ambiental, jogo, percepção ambiental.

\section{INTRODUCTION}

Aspects related to the theme of environmental issues are increasingly becoming the focus of discussions in different areas of knowledge. In the area of education, this debate aims to obtain technical and scientific solutions to instill environmental knowledge, mainly in basic education (Jacobi, 2005).

The arrival of the 3rd Technological Revolution in the 1980s led to the emergence of Information and Communication Technologies (ICTs) and, among them, those used by teachers for the teaching and learning of the student (Kenski, 2008). Computer programs developed specifically for educational purposes are called multimedia educational programs and for the most part, they are software-created with the teaching/learning bias (Coscarelli, 2002).

Educational games (Tajra, 2000) aim to stimulate students' skills and knowledge, which, by using playfulness, improves their learning. The attractions offered by the media lead them to be motivated by their studies (Roloff, 2010; Tajra, 2000).

Basically, one of the drivers of this technology was the creation of video games in 1971. However, the interest in creating educational games with a focus on ecological themes only 
happened twenty years later (Audureau and Lamy, 2019).

At the same time that, globally, actions turned to environmental discussions, several governmental actions of an environmental nature were carried out in Brazil, which published, in 1981, its National Environment Policy (Law 6938/81), whose premises and concepts were consolidated in the Brazilian Constitution in 1988.

In Brazil, digital games focused on environmental design appeared after the Rio 92 Conference with the celebration of the Environmental Education Treaty for Sustainable Societies and Global Responsibility (Gama et al., 2012), as from Rio 92 digital games were developed with the purpose of promoting environmental education (Rocha, 2019).

Since the 1988 Constitution, with the realization of RIO 92 and the development of a global collective conscience of the environment, Brazil has implemented important policies in this context, among which, the National Water Resources Policy (Law 9433/1997), the National Environmental Education Policy (Law 9795/1999), which represented important legal advances in the field of Environmental Education, bringing in core principles that define that environmental education must be permanent and continuous, the National Solid Waste Policy (PNRS), established by Law no. 12,305, of August 2, 2010.

With a focus on environmental education, studies involving the visit of students in watersheds have been developed by several authors in Brazil. In general, according to Baião and Batista (2017) the target audience of Environmental Education programs aimed at the study of the Hydrographic Basin are the students. However, the approach and the age range vary, among which can be mentioned: Batista et al. (2005) teachers and students of Early Childhood and Elementary Education involved the neighborhood community. Callisto et al. (2002), Schiel et al. (2002) and Lucatto and Talamoni (2007) worked in the training of professionals (undergraduate students and teacher-multiplier); Scatena (2005) and Kudryavtsev et al. (2012) carried out their research with high school students; Shepardson et al. (2007) carried out the survey with elementary and high school students; Bergmann and Pedroso (2007) worked with classes in the 9th grade of elementary and high school and Chung and Lima (2007) and Guimarães et al. (2012) developed the work with all Elementary School from 6th to 9th grade.

More recently, Targa et al. (2017) worked with 8th grade students and Queiroz and Dornfeld, (2019) worked with 6th grade students.

The National Water and Basic Sanitation Agency (ANA, 2016) created in 2000 as an action of the National Water Resources Policy, with the purpose of organizing, supervising and planning the Brazilian water system, in partnership with the Coordination for the Improvement of Higher Education Personnel (CAPES), a public foundation linked to the Ministry of Education (MEC) which, as of 2007, started to act, also, in the training of basic education teachers.

In this context, ANA and CAPES supported several projects through the call for proposal $\mathrm{N}^{\circ} .42$ of 2017, named "Education on Virtual Games", in order to encourage pedagogical innovation through the development and dissemination of technological tools for use in teaching, to promote improvement of public higher education quality through innovative teaching-learning methods and practices, aiming at the convergence between classroom and distance education modalities, through the promotion of innovative projects in the use of ICTs in education (Fundação Capes, 2017).

The main objectives of the games created by Brazilian universities (Table 1) are to didactically and interdisciplinarily touch the topics of water such as watersheds, health, water quality, consumption, hydrological cycles, perception of the environment in everyday life and also questions about sustainability and quality of life in elementary and high schools.

One of these games, Educa-Ação-Água (Table 1), developed by Targa et al. (2017) at the University of Taubaté (UNITAU), uses a hypothetical hydrographic basin (Tijuco River basin) as a game locus characterized by an area of $1894 \mathrm{~km}^{2}$ comprising 4 municipalities, which add 
up to 192 thousand inhabitants.

Table 1. Digital water-themed games produced by Higher Education institutions in Brazil for use by elementary and high schools.

\begin{tabular}{|c|c|c|}
\hline Digital Game & HEI & LINK \\
\hline $\begin{array}{l}\text { Water and Community: } \\
\text { building sustainable } \\
\text { solutions }\end{array}$ & $\begin{array}{l}\text { Universidade do Sul e } \\
\text { Sudeste do Pará }\end{array}$ & $\begin{array}{c}\text { https://capacitacao.ana.gov.br/conhecerh } \\
\text { /handle/ana/236 }\end{array}$ \\
\hline Water Calculation & $\begin{array}{l}\text { Universidade de } \\
\text { Uberaba }\end{array}$ & $\begin{array}{c}\text { https://play.google.com/store/apps/detail } \\
\text { s?id=com.nelltech.apps.calculodeaguas } \\
\& \text { hl=ptBR }\end{array}$ \\
\hline $\begin{array}{c}\text { The cost of bathing and water } \\
\text { reuse }\end{array}$ & $\begin{array}{l}\text { Centro Universitário } \\
\text { Franciscano }\end{array}$ & $\begin{array}{l}\text { http://maisunifra.com.br/wp- } \\
\text { content/uploads/objeto_ANA/ }\end{array}$ \\
\hline $\begin{array}{l}\text { Didactic game: Water and } \\
\text { Sustainability }\end{array}$ & $\begin{array}{l}\text { Universidade Federal da } \\
\text { Fronteira Sul }\end{array}$ & $\begin{array}{c}\text { https://capacitacao.ead.unesp.br/conhece } \\
\text { rh/handle/ana/290 }\end{array}$ \\
\hline $\begin{array}{l}\text { Didactic game: Water and } \\
\text { Sustainability - High School }\end{array}$ & $\begin{array}{l}\text { Universidade Federal da } \\
\text { Fronteira Sul }\end{array}$ & $\begin{array}{c}\text { https://capacitacao.ead.unesp.br/conhece } \\
\text { rh/handle/ana/290 }\end{array}$ \\
\hline $\begin{array}{l}\text { Digital Game: Adventure in the } \\
\text { waters }\end{array}$ & $\begin{array}{l}\text { Universidade Estadual } \\
\text { Paulista }\end{array}$ & $\begin{array}{c}\text { http://www.feis.unesp.br/aventuranasagu } \\
\text { as/\#/register }\end{array}$ \\
\hline Digital Game: Generation Water & Universidade Feevale & $\begin{array}{l}\text { http://games.feevale.br/redeteia/games.ht } \\
\mathrm{ml}\end{array}$ \\
\hline Memoágua & $\begin{array}{l}\text { Universidade de } \\
\text { Uberaba }\end{array}$ & $\begin{array}{c}\text { http://www.escolagames.com.br/jogos/u } \\
\text { niube/memoAgua/ }\end{array}$ \\
\hline Mission Planet Water & $\begin{array}{l}\text { Universidade de } \\
\text { Uberaba }\end{array}$ & $\begin{array}{c}\text { http://www.escolagames.com.br/jogos/u } \\
\text { niube/missaoPlanetaAgua/ }\end{array}$ \\
\hline $\begin{array}{c}\text { Domestic Footprint and Rational } \\
\text { Water Use }\end{array}$ & $\begin{array}{l}\text { Universidade de São } \\
\text { Paulo }\end{array}$ & http://projetoagua.murilobeltrame.com/ \\
\hline $\begin{array}{l}\text { Tec-Iara: games for learning and } \\
\text { valuing water in indigenous } \\
\text { territories in Bahia }\end{array}$ & $\begin{array}{l}\text { Instituto Federal de } \\
\text { Educação, Ciência e } \\
\text { Tecnologia Baiano }\end{array}$ & $\begin{array}{c}\text { https://play.google.com/store/apps/detail } \\
\text { s?id=br.edu.ifbaiano.kiriri.kiriri }\end{array}$ \\
\hline Educa-ação-água & Universidade de Taubaté & $\begin{array}{c}\text { http://ipabhi.org/educa-acao-agua- } \\
\text { unitau. }\end{array}$ \\
\hline
\end{tabular}

Source: (ANA), 2017.

The hydrographic basins, territorial units for the management of water resources (Brasil, 1997) are open systems formed by a series of complex and interconnected principles, of which, within the human vision, the dependence on water in terms of survival and economy stand out.

For Morin (2006), a multidimensional view contributes to the understanding of the real world's complexity. In this view, knowledge should not be compartmentalized, as this can reduce overall knowledge, leading society to error. Questioning the existing paradigms is needed, so that one can unify and face the tangle of interactions existing in these open systems with conceptual tools that approach the unit without separating it or hierarchizing it from the set and vice versa, recognizing the uncertainties and the incomplete nature of knowledge.

Therefore, it is important that mankind develops an in-depth knowledge about this theme, conceiving each element and process existing in hydrographic basins as an integral part of a set that may interfere with water availability. 
According to Baião and Batista (2016), within this principle several authors such as Schiel et al. (2002), Callisto (2002), Batista et al. (2005), Scatena (2005), Bergman and Pedrozo (2008) and Guimarães et al. (2012) explored the hydrographic basin, involving teachers, students and communities, through a study of the environmental conditions of this territorial unit in which knowledge about soil, relief, geology, vegetation, fauna, climate, anthropic impacts and recovery possibilities were explored .

In this context, the Educa-Ação-Água project (Table 1) was conceived with the purpose of contributing to foster new modeling alternatives in teaching, understanding, technological diffusion in the assessment of water balance, through the joint analysis of aspects of quantity and water quality in hydrographic basins, and being accessible to the different levels of pedagogical needs of teachers and schools, in addition to promoting the concept of citizenship, sharing the collective use of natural resources existing in the Brazilian territory (Targa et al., 2017).

The Tijuco River is $93 \mathrm{~km}$ long, formed by 10 tributaries that are subject to the effects of human activities in the basin. Thus, some economic activities, such as industry and agriculture, the misuse of water and soil, deforestation and poor water management are damaging the river, reducing its quantity and quality of water, bringing very bad consequences for the population that so much depends on it for its supply. Basically, the game consists of the student answering questions related to anthropic activities and water management in the hydrographic basin and adding a number of points, which will be used in the next phase in proposing actions to save the Tijuco River, acting as a caregiver or manager of water (Targa et al., 2017).

Therefore, the present study aimed to encourage students to recognize the importance of human water using a digital game and to verify the students' opinions and assessment regarding the game and the value it added to their learning.

\section{MATERIAL AND METHODS}

\subsection{Location}

The present study was developed in a Municipal Elementary School of the educational network of the municipality of Taubate, SP, which is located at the coordinates of $23^{\circ} 01^{\prime} 30^{\prime \prime}$ South Latitude and 4533'31" West Longitude, in the Paraíba Valley region, São Paulo, Brazil (Figure 1).

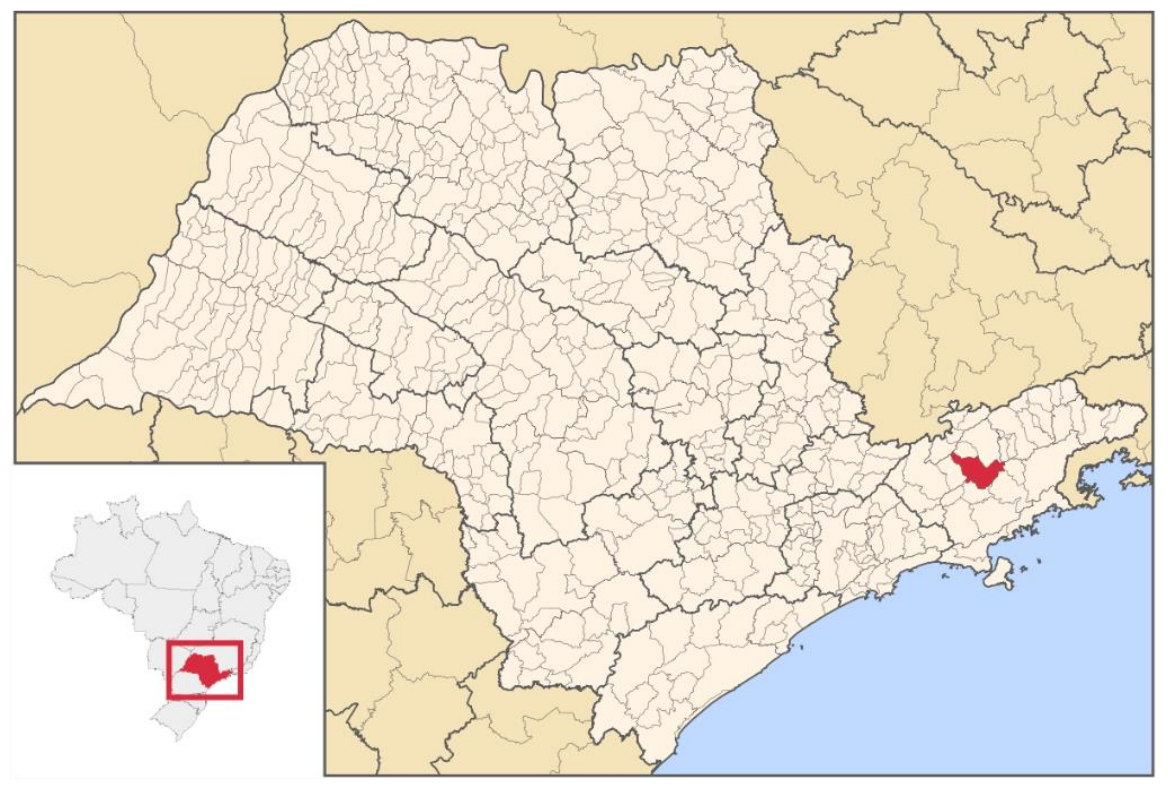

Figure 1. Municipality of Taubaté, Vale do Paraíba, São Paulo, Brazil 


\subsection{Methodological procedure}

Initially, the number of students who should participate in the study was defined using the online sample calculation tool developed by Santos (2011). The sample size is calculated using Equation 1, according to the $95 \%$ confidence level and the absolute sample error of $5 \%$.

$n=\frac{N * Z^{2} * p *(1-p)}{Z^{2} * p *(1-p)+e^{2} *(N-1)}$

Where:

$\mathrm{n}$ - calculated sample

$\mathrm{N}$ - population

$\mathrm{Z}$ - standardized normal variable associated with confidence level

$\mathrm{p}$ - true probability of the event

e - sampling error

According to information from Taubate Mayor's Office records in 2019, the total number of students enrolled in the 8th grade of elementary school in the Municipal Network of Taubaté is 3,237 students; however, the school unit under study has 119 students in the 8th grade. Considering $\mathrm{N}=3,237, \mathrm{Z}=95 \%, \mathrm{p}=50 \%$, and $=10 \%$, we arrive at the sample value of 92 students.

This Methodology was approved by the Ethics Committee with Research on Human Beings of the University of Taubaté (Approval Protocol is 2.975.670), parents and / or guardians signed the Free and Informed Consent Form (FPIC) and the students, the Informed Consent Form (ICF).

The study was carried out with 63 students from the 8th grade, with ages varying from 13 to 14 years old, since several students did not participate, either due to lack of computers, being absent on the scheduled day, for not having authorization from their parents or guardians for activity outside the school, etc.

The methodological procedures were organized in four stages, the first was to raise students' awareness of the topic addressed and consisted of extra-class activity with students visiting the company responsible for capturing, treating and distributing water, as well as removing and treating municipal sewage.

Firstly, we visited the Water Catchment Station on the Una River, located at the coordinates $23^{\circ} 01^{\prime} 50^{\prime \prime} \mathrm{S}$ and $45^{\circ} 30^{\prime} 28^{\prime \prime} \mathrm{W}$. Then, the students visited the ETA (Water Treatment Station) of Taubaté, located at $23^{\circ} 01^{\prime} 15.09^{\prime \prime} \mathrm{S}$ and $45^{\circ} 31^{\prime} 24.01^{\prime} \mathrm{W}$, observing the treatment phases and the entire water distribution process.

In the second stage of this study, the students' previous perceptions regarding the water topic were evaluated through the application of a first questionnaire, with open questions, developed in school-level language.

The third stage consisted of a test of the digital game Educa-Ação-Água by the students. As the game activity would be performed in digital form, it was proposed that students use the computers of the computer lab of the teaching unit or their personal equipment.

The fourth step proposed by the teacher evaluated the digital tool through the application of a second questionnaire. The questions were of a quantitative nature and were divided into open (dissertative) and closed (multiple choice) questions, aiming to collect data and conduct a survey of the participants' perceptions of the digital game "Educa-Ação-Água".

The WordClouds.com (2019) tool was also used in this study to create word clouds, using one of the various shapes and images available in the tool to graphically represent results for the use of water and the game. 


\section{RESULTS AND DISCUSSION}

Initially, it was found that the 63 (sixty-three) students of the 8th grade enrolled to participate in the activity had delivered the documentation (TCLE and TALE) properly signed and, therefore, were able to participate in the study.

According to Brasil (1998), the topic "water and hydrographic basins" described in the National Curriculum Parameters for the Environment in the discipline of Geography is conceptualized in the 6th grade of Elementary School II. In the National Common Curricular Base (BNCC), the Geography component addresses the thematic unit nature, environments and quality of life in the 6th year (Brasil, 2017).

As the objective was to verify students' perception of the game and not only their knowledge, its application in the 8th grades was important, as the theme of watersheds had already been addressed in the discipline of Geography in previous school years, facilitating the understanding of the issues involved in the game, providing students with greater focus on the game.

\subsection{The students' technical visit to the water treatment plant}

The visit to the company responsible for capturing, treating and distributing water, aimed to raise students' awareness of the water issue, in order to verify their level of perception related to water resources and to verify their level of water usage, contents previously taught in the discipline of Geography.

In this activity, sixty-six students participated in a monitored visit to the Water Catchment Station on the Una River and the Water Treatment Station (ETA). The visit took place, on purpose, on March 21, the eve of World Water Day (March 22). Of the 66 students, 18 (eighteen) were from 8th grade A, 24 (twenty-four) from 8th grade B, 10 (ten) of the 8th grade $\mathrm{C}$ and 14 (fourteen) of the 8th grade D.

In this activity, the students were able to learn about the water collection process, showing the quantity of water and the quality of the water collected, its previous treatment and the pumping system for final treatment. They were also able to observe their water quality in terms of sediment amount present in Una River's water as a reflection of the poor land use, deforestation of the riparian forest, agricultural activities and the increase of urban growth in the mid course of the Una River and the problems that silting brings to the collection processes, because on that date there was a clogging of the 03 (three) water collection pumps.

Then, the students visited the WTS (Water Treatment Station) of Taubate, located at the coordinates $23^{\circ} 01^{\prime} 15.09^{\prime \prime} \mathrm{S}$ and $45^{\circ} 31^{\prime} 24.01^{\prime \prime} \mathrm{W}$, observing the treatment phases and the entire process of water distribution to the municipalities of Taubaté, Tremembé and part of Caçapava.

At the WTS, the students listened to a lecture by the company's technician explaining the quantity and importance of water for humanity and the need to preserve it. Then they visited the outside of the station watching the arrival, through a pipe, of $15001 / \mathrm{s}$ of water collected from the Paraíba do Sul River, to complement the water captured from the Una River.

Regarding treatment, students were able to observe the following phases:

a. Pre-chlorination - First, chlorine is added as soon as the water reaches the station. This facilitates the removal of organic matter and metals.

b. Pre-alkalinization - After chlorine, the water receives lime or soda, which serves to adjust the $\mathrm{pH} *$ to the values required in the next stages of treatment.

c. Coagulation - In this phase, aluminum sulfate, ferric chloride or another coagulant is added, followed by a violent stirring of the water. Thus, dirt particles are electrically destabilized and easier to aggregate.

d. Flocculation - After coagulation, there is a slow mixing of the water, which serves to 
cause the formation of flakes with the particles.

e. Decanting - In this process, the water passes through large tanks to separate the flakes of dirt formed in the previous step.

f. Filtration - Soon after, the water passes through tanks formed by stones, sand and anthracite coal. They are responsible for retaining the dirt that remains from the decantation phase.

g. Post-alkalinization - Then, the final correction of the water $\mathrm{pH}$ is made, to avoid corrosion or incrustation of the pipes.

h. Disinfection - One last addition of chlorine is made to the liquid before it leaves the Treatment Station. It ensures that the water supplied arrives free from bacteria and viruses to the consumer's home.

i. Fluoridation - Fluorine is also added to water. The substance helps to prevent cavities.

The students were thrilled to see the resulting clean water that once was dark-colored due to sediments.

\subsection{First survey form}

The students enrolled in this study, already identified from the first survey form to which they belonged, answered the first form with open questions (dissertations), through the Google Forms Platform, in order to verify the level of prior knowledge they already had about the water theme. From the responses of each student, a grouping by type of answer can be elaborated.

The results described in Table 2 were collected from the responses of students from the 8th year of high school, regarding the question of what is the hydrographic basin.

Table 2. Student responses on watershed (2019).

\begin{tabular}{cc}
\hline Answer & Students number \\
\hline Main river and its tributaries & 37 \\
Runoff surface & 12 \\
Water catchment area & 07 \\
It's a lot of water & 03 \\
Others & 02 \\
\hline Total & 61 \\
\hline
\end{tabular}

It was found that the students' responses were related to the classic definition, that is, to the geophysical aspects and water resources.

It was found that of the 61 students who answered the question about what a hydrographic basin is, 37 (thirty-seven) students answered that it is the main river and its tributaries, which corresponded to $60.65 \%$ of the students, and $12(20 \%)$ answered that it was a runoff surface and $3(5 \%)$ that it was a water catchment area. The answers given by these students are similar to the concept of the hydrographic basin given by Barrella et al. (2000), as a set of lands drained by a river and its tributaries, formed in the highest regions of the relief by river dividers, where the rainwater either drains superficially forming streams and rivers, or infiltrates the soil to form springs and groundwater, as well as those of Guerra and Guerra (2008) and Silva (1995), as a set of lands drained by a river and its tributaries.

Regarding the question of whether there was a river near the house where they lived, only 61 students answered this question, and of these, 21 (twenty-one) or $34.4 \%$ said yes and of those, 08 (eight) only mentioned the Paraíba do Sul River and / or the Una River, in addition to 04 (four) referring to Ribeirão do Pinhão, they mentioned it as a stream that is close to the neighborhood where they live. 
It appears that 25 (twenty-five) students replied that they did not pass any river near their homes and 2 (two) complemented the answer, one of them replied that his water came from a dam and the other referred to several rivers. In fact, a person may not live near a river, but the important thing in this case is the mental exercise that the student does in relation to the geographic space where he lives.

Regarding this issue, in general, it was observed that most players already had some knowledge about the hydrographic basin where they lived, counting those who said yes, plus those who mentioned the Paraíba do Sul and/or Una Rivers and the stream, 54\% of respondent students were added. It is believed that this result was probably due to the visit they made to the Catchment Station and the Water Treatment Station.

The question regarding where the water consumed at home comes from, of the 60 students who answered this question, 25 students $(41.66 \%)$ answered that it came from the Paraíba do Sul River and / or Una River, 24 students $(40 \%)$ responded that the water came from the Water Treatment Station (ETA) of the Basic Sanitation network in the state of São Paulo (SABESP), which reinforces the idea that the visit and previous knowledge of the geography discipline provided a better response from the students.

Regarding the question that asked students to describe an activity in their daily lives that proved the importance of rivers, the WordClouds.com tool was used to create word clouds using one of the various shapes and images available in the tool to represent graphically the results of the activities described by the students in the use of water (Figure 2). The students' response consisted largely of terms such as bathing, drinking water, washing clothes and dishes, brushing teeth, among others.

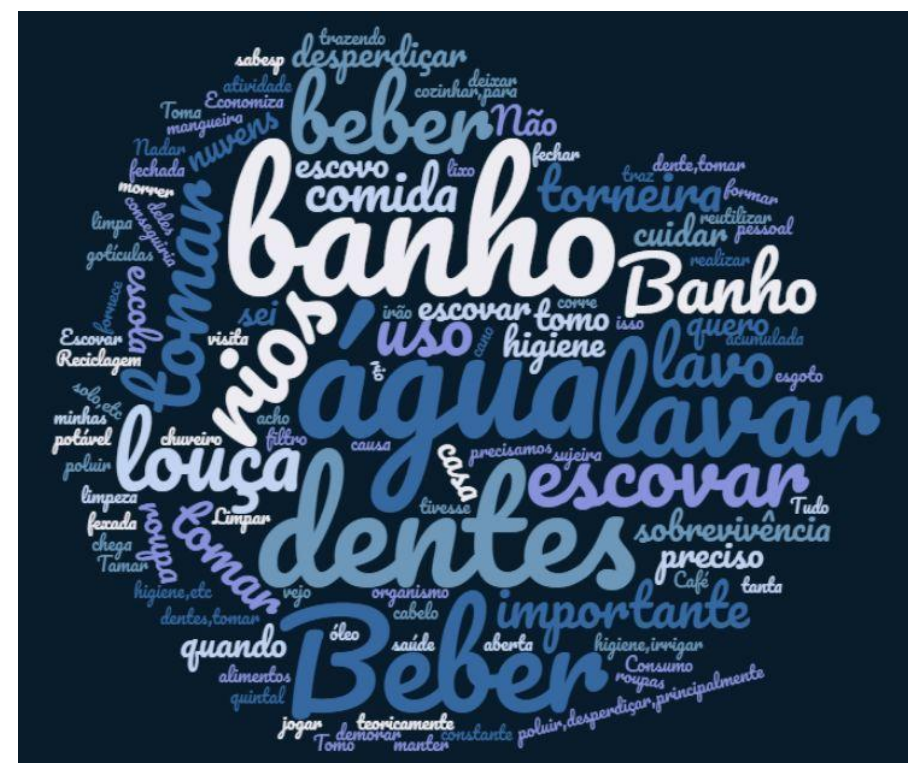

Figure 2. Word cloud refers to the activities carried out on a daily basis by 8 th-grade students and which proved the importance of rivers.

The results of the answers obtained in this study about the activities performed by 8 th grade students in the use of water, are very consistent with that obtained by Rodrigues (2010) who in his question to students asks: "Do you know the utility of water?", it was found that all students answered yes and mentioned drinking water, washing dishes, bathing, making food, among others. This exercise is very important for students, as their answers are related to consumption situations.

Regarding the question about what threatens water quality on the planet, we also tried to use the WordClouds.com tool to create the word cloud (Figure 3). 


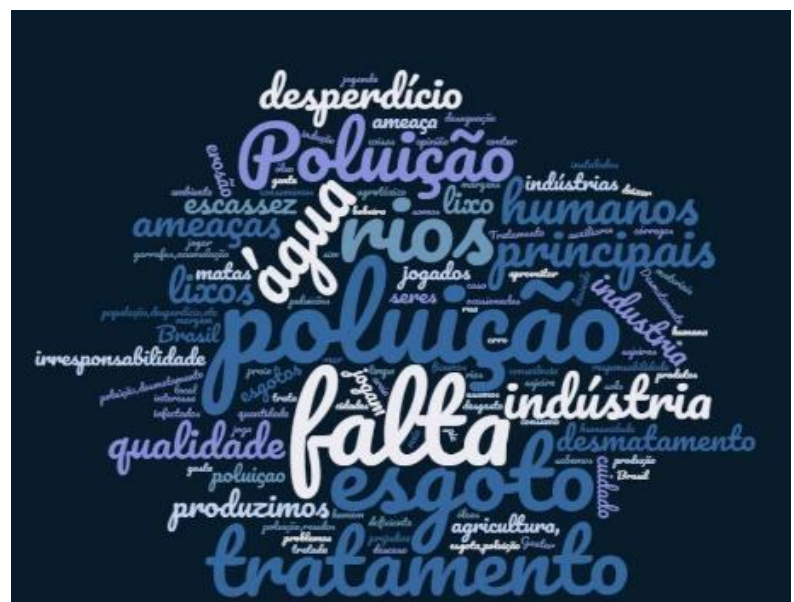

Figure 3. Word cloud referring to the responses of 8th grade students about what threatens the quality of water on the planet.

Analyzing the results expressed in Figure 3, it can be seen that students have a good perception about the issues of pollution, lack of water, sewage, treatment, and to a lesser extent about waste and industrial use, and that this result expresses the concepts worked on in previous years with students from the municipality of Taubaté.

\subsection{Activity with the game "Educa-Ação-Água}

The third methodological stage of the project aimed to apply the digital game "EducaAção-Água"; however, of the sixty-seven students who signed up to participate in the game activity, only 57 students played, and of these it was identified that 21 belonged to 8th grade A; 20 to 8 th grade B; 8, to 8th grade C and 8 to 8 th grade D. Several reasons led some students to forgo the activity, mainly accessibility to equipment and/or the internet.

In the Educa-Ação-Água game, 19 places were distributed in the hydrographic basin, with the possibility of intervention by the students and with more than 600 possibilities of interventions, distributed in these 19 places, to provoke a process of improvement seeking by the student, which is the objective of the game, challenging their knowledge to progressively and continuously improve the water. In this sense, a large number of activities were created and introduced in the game to promote the alteration of the initial condition of the water in the river basin in order to show that human interventions (positive or negative) are those that promote the alteration of any existing situation in the environment.

These criteria defined, on the one hand, the main objective that was intended to associate: a) Knowledge acquired by the student being transformed into points accumulated in Step (2) of the game; b) The stimulus and its ability to intervene in a situation with elements of reality to make improvements in a situation of a river that was notably deteriorated in several aspects by the accumulation of human activities. To associate "acquired knowledge" with "elements of reality", the following items were selected for the composition of the situation of the Basin to be the object of intervention in step 3 of the game:

1) The relationships between availability of water in the basin as a consequence of environmental preservation (and / or) recovery actions, thus showing the existing relationships between different elements of the environmental system;

2) The relationship between the environmental situation of the waters of the basin river with the existence (or not) of water treatment, sewage treatment, educational initiatives such as: rational use of water, reduction of loss, and attitudes of hygiene;

3) The relationship between the existence of water (and sewage) treatment, construction

Rev. Ambient. Água vol. 7 (supplement) - Taubaté 2020 
of rainwater galleries, cleaning of rainwater and sewage drainage ditches, and the possibility of reducing diseases (Zika, Dengue and Chikungunya and other airborne diseases) as well as infant mortality.

4) The relationship between initiatives and actions of an educational nature dealt with in school or city campaigns, which contribute (in a little perceived way) to the reduction of various types of diseases and thus contribute to improving the condition of availability for work (and other activities in general) of any citizen.

5) The perception that interventions carried out in the basin (regardless of their position or type) can promote improvements in the environmental situation, in the different conditions of the basin, with consequences for the improvement of people's living conditions. As for the basic structure, in addition to portraying and reproducing these objectives and environmental relationships, after evaluating several design alternatives, in which a large part of the project time was spent, it was concluded that the tool to be developed should have 3 successive work steps according to the scheme in Table 3.

Table 3. Basic structure of the successive work stages of the game Educa-Ação-Água.

\begin{tabular}{ccc}
\hline Step 1 & Step 2 & Step 3 \\
\hline Teacher or supervisor & Student / user / player & Student / user / player \\
\hline $\begin{array}{l}\text { Preparatory with the choice } \\
\text { of level and 3 work themes }\end{array}$ & $\begin{array}{c}\text { Answers questions and activities } \\
\text { proposed by the teacher and } \\
\text { accumulates points }\end{array}$ & $\begin{array}{c}\text { Use the points accumulated in Step } \\
\text { 2 to improve the situation of the } \\
\text { river. }\end{array}$ \\
\hline
\end{tabular}

\subsection{Second survey form}

The fourth stage of this study was to apply to students the final questionnaire with closed (multiple choice) and open (dissertation) questions, using a form available on the Google Forms Platform. These responses were subsequently compiled for the analysis procedure.

Through the first question corresponding to the identification of students, it was found that only 60 students answered Question 1 and it was possible to identify that 24 students belonged to 8th grade B, 19 to 8th grade A, 9 to 8th grade D and 8 to 8th grade C. After participating in the activity and with reference to Question 2 on the evaluation they made of the game EducaAção-Água, 21 students answered that the game is very good, 31 answered good and 5 that it is reasonable and 3 students thought the game bad. Thus, it appears that 52 students $(86.66 \%)$ liked the game and would play again.

In Question 3, students were asked to cite the lessons they learned from the game. Fortyeight responses were obtained on Google Forms, and the most frequent responses were the importance that rivers, riparian forests and watersheds have in our lives, in addition to the importance of saving and reusing water, among others. The corresponding WordClouds.com word cloud (Figure 4) was then obtained:

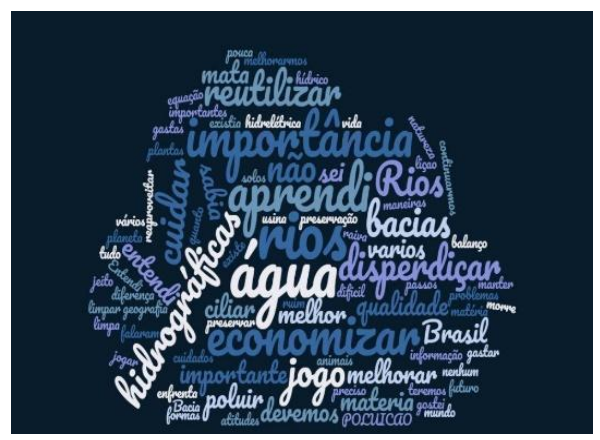

Figure 4. Learning acquired by students when playing Educa-AçãoÁgua (2019). 
In the work developed by Dornfeld et al. (2019), it was observed that most students in the 6th and 9th grades of elementary school II and 3rd grade of high school responded in a similar way to students from Taubaté who learned about water awareness and saving, but also on waterborne diseases and multiple uses of water, among others.

From Question 4 of this current work, "What is the level of the questions worked within the contents that include the water theme?", Considering a scale of 1 (Very Good) to 5 (Very Bad), it was found that 31 students (52\% ) opted for the 3- Regular level, 13 students for the 5Very Good level, 09 students for the 4- Good level and 05 students for the 2- Bad and 1- Very Bad levels. It is believed that the majority of students found the level of questions to be reasonable, as they had already worked on the topic in previous series subjects.

Considering the interaction young people currently have with digital games, considering a scale of 1 to 5 as in the previous question, Question 5, referred to the "way of playing". It was found that 27 students (45\%) opted for level 3, that is, regular play. While 10 students $(16.6 \%)$ opted for the level 1- Very Good, 09 students (15\%) for the level 2- Good, 08 students, 4- Bad and 06 students for the level 5- Very Bad. A youngster's adherence to a digital game is closely related to the level of difficulty presented to him when playing, which becomes motivation. However, in the educational game, the dispute to know who is the best should not exist, as it would make the student lose the focus of learning, because its objective is to stimulate the students' skills and knowledge (Tajra, 2000). Therefore, in these types of games, motivation should prevail to finish the game in the best possible way, based on your knowledge. In this work, it is possible to recognize that the attractions offered by the media led the student to be motivated by the study (Roloff, 2010), which is corroborated by the answers to Question 6, in which $88 \%$ of the students stated that they felt encouraged to complete the stages of the game "Educa-Ação-Água" and improving the water quality of the Tijuco River. In addition, regarding Question 7, 39 students (65\%) would like to have more classes with this type of activity and that they would play this game at home in their spare time.

Finally, the eighth and final question on their opinion about the game, found that not only did most students enjoy the game, but they were also able to develop a critical sense of the game itself and expressed their opinion which they recorded up:

- Most students thought the game was very good, well designed, but the questions were difficult to answer;

- The tool helped in their learning process, teaching new things, how to take care of water, and even a life lesson;

- They claimed to be great for stimulating knowledge;

- The method and its handling are easy, but the vocabulary somewhat difficult, making it necessary to research the meaning of certain words;

- Guidance is missing in some stages of the game;

- There should be more questions that better explain water treatment;

- Have the answers at the end of the game;

- Some errors were generated during the game, such as crashes, causing the player to be unable to finish the game, being necessary to start it again;

- There should be more drawings and images;

- Difficulties in the issue of the little cross;

- There was a lack of clearer indication of the end of the game after the player made the necessary improvements to the Tijuco River Basin.

These aspects pointed out by the students enriched this study a lot, as it demonstrated that

Rev. Ambient. Água vol. 7 (supplement) - Taubaté 2020 
they understood the proposal as a stimulus to knowledge (great to stimulate knowledge, helped in their learning), although they mastered the technology (method and its handling are easy), they realized knowledge difficulties of specific technical terms in the area of water resources (vocabulary somewhat difficult), but they had the dexterity to research the meaning. The fact that they visited a water collection and treatment station made it possible to verify that in the game they should have more questions about this. In general, they suggested possible improvements such as having more drawings and images, having the answers to the questions and an indication of the completion of the game after improvements were made in the Tijuco River Basin.

These observations are important, since the management of water resources, environmental education, and many other policies related to these themes, are recent in Brazil. The game Educa-Ação-Água enabled the recognition of hydrographic basins as a territory where one lives (Brasil, 1997), and the development of a multidimensional vision contributes to the understanding of the complexity of the real world (Morin, 2006).

In education, the use of digital games does not exclude field visits. However, the form of study with digital games allows a large number of important interactions to understand the complex, but real use and occupation relationships that occur in the hydrographic basin as a complex territorial system. In the Educa-Ação-Água game, for example, 19 locations with the possibility of intervention by the students were distributed in the hydrographic basin and with more than 600 intervention possibilities distributed in these 19 places, something that local visitation alone would not allow the students to interact with (Targa et al., 2017).

\section{CONCLUSIONS}

The activity with the digital game Educa-Ação-Água led to students' awareness and learning about the water theme, making them recognize its importance and developing critical sense.

In evaluating the game, it was observed that $51.6 \%$ of the students rated the game as "Good" and 35\% of them rated it as "Very Good"; $88 \%$ felt encouraged to finish the game (Save the Tijuco River) and about $65 \%$ would play again at home or in the classroom.

There was a contribution from students (players) when evaluating the game Educa-AçãoÁgua, pointing out points to be improved.

\section{REFERENCES}

ANA (Brasil). ConheceRH. Acervo Educacional Sobre Água. Brasília, 2016. Available: https://capacitacao.ana.gov.br/conhecerh/handle/ana/140 Access: 21 Sep. 2020.

AUDUREAU, W.; LAMY C. Les jeux vidéo peuvent-il sensibiliser à la cause écologique? Le Monde, 01 abr. 2019.

BAIÃO, C. F. de P.; BATISTA, G. T. Watershed evaluation by elementary school students: contribution to water resources teaching. Revista Ambiente \& Agua, v. 11, n. 5, p. 10561067, 2016. http://dx.doi.org/10.4136/ambi-agua.1895

BAIÃO, C. F. P.; BATISTA, G. T. Ampliação da Concepção Ambiental: Contribuição metodológica com o estudo de bacia hidrográfica para a Educação Básica. 1. ed. Feira de Santana: Novas Edições Acadêmicas, 2017. v. 1. 113p.

BARRELA, W.; PETRERE, M.; WELBER, S. S.; ASSIS MONTAG, L. As relações entre as Matas ciliares, os rios e os peixes. In: RODRIGUES, R. R.; LEITÃO-FILHO, H. F. (eds.). Matas ciliares: Conservação e recuperação. São Paulo: EDUSP/FAPESP, 2000. p. 187208. 
BATISTA, G. T. et al. Educação Ambiental voltada para os Recursos Hídricos: Um Estudo de Caso. Taubaté: Unitau, 2005. Available at: http://www.agro.unitau.br/caieiras/arquivos/proposta_projeto.pdf Access: 13 Oct. 2020.

BERGMANN, M.; PEDROSO, S. Explorando a bacia hidrográfica na escola: contribuições à Educação Ambiental. Ciência e Educação, v. 14, n. 3, p. 537-553, 2008.

BRASIL. Ministério da Educação. Base Nacional Comum, Resolução CNE/CP No 2, de 2017. Brasília, DF, 22 dez. 2017. Available at: http://basenacionalcomum.mec.gov.br. Access: 08 Sep. 2019.

BRASIL. Secretaria de Educação Fundamental. Parâmetros curriculares nacionais: meio ambiente. Brasília,1998.

BRASIL. Secretaria de Educação Fundamental. Parâmetros curriculares nacionais: Geografia. Brasília: MEC/SEF, $1997 . \quad$ Available at: http://portal.mec.gov.br;seb;arquivos/pdf/geografia.pdf. Access: 12 Oct. 2019.

CALLISTO, M. et al. Aplicação de um protocolo de avaliação rápida da diversidade de habitats em atividades de ensino e pesquisa (MG-RJ). Acta Limnologica Brasiliensia, v. 14, n. 1, p. 91-98, 2002.

CHUNG, F.; LIMA, M. M. V. de. Educação Ambiental com Ênfase na Preservação dos Recursos Hídricos no Município de Campos do Jordão-SP. In: SEMINÁRIO DE RECURSOS HÍDRICOS DA BACIA HIDROGRÁFICA DO PARAIIBA DO SUL: o Eucalipto e o Ciclo Hidrológico, 2007, Taubaté. Anais eletrônicos[...] Taubaté: IPABHi, 2007. Available at: http://www.agro.unitau.br/serhidro/doc/pdfs/131-137.pdf Access: 13 Oct. 2020.

COSCARELLI, C. V. A informática na escola. Belo Horizonte: FALE, Universidade Federal de Minas Gerais, 2002. Available at: http://www.letras.ufmg.br/carlacoscarelli/publicacoes/Vivavoz.pdf. Access: 12 Jul. 2019.

DORNFELD, C. B.et al. Aplicação do Jogo Digital "Aventura nas Águas" em Três Escolas Públicas de Educação Básica do Estado de São Paulo. In: DORNFELD, C. B.; TALAMONI, A. C. B.; QUEIROZ, T. V. O Jogo digital na sala de aula - Água, Ação e Reflexão: elaboração de jogo digital para a Educação Básica. São Vicente: Unesp, 2019. Cap.6, p. 74-89. Available at: https://capacitacao.ana.gov.br/conhecerh/bitstream/ana/752/1/Dornfeld-TalamoniQueiroz-2019-E-book-Jogos\%20digitais-Agua-acao-reflexao.pdf. Access: 20 Oct. 2019.

FUNDAÇÃO CAPES. Edital no 42/2017 - Educação na temática Jogos Virtuais. Available at: https://www.capes.gov.br/editais-ded/8658-educacao-na-tematica-jogos-virtuais. Access: 12 Oct. 2019.

GAMA, S. V. G.; CARVAlHO, D. T.; CARVAlHO JUNIOR, R. P. C. Geografia, planejamento ambiental e educação ambiental: entre os parâmetros legais e as práticas $\begin{array}{llllllll}\text { reais. Geo UERJ, } & \text { v. 2, n. 23, p. 524-551, } 2012 .\end{array}$ https://doi.org/10.12957/geouerj.2012.4817

GUERRA, A. T.; GUERRA, A. J. T. Novo Dicionário Geológico-Geomorfológico. 6. ed. Rio de Janeiro: Bertrand Brasil, 2008. p. 648. 
GUIMARÃES, et al. Adequação de um protocolo de avaliação rápida de rios para ser usado por estudantes do ensino fundamental. Revista Ambiente \& Água, v. 7, n. 3, p. 241-260, 2012. http://dx.doi.org/10.4136/ambi-agua.996

JACOBI, P. R. Educação Ambiental: o desafio da construção de um pensamento crítico, complexo e reflexivo. Educação e Pesquisa, v. 31, n. 2, 2005. Available at: http://www.scielo.br/scielo.php?script=sci_arttext\&pid=S1517-7022005000200007. Access:15 Sep. 2019.

KENSKY, V. M. Educação e tecnologias: o novo ritmo da educação. 3. ed. São Paulo: Papirus, 2008 .

KUDRYAVTSEV, A. et al. The impact of environmental education on sense of place among urban youth. Ecosphere, v. 3, 2012. https://doi.org/10.1890/ES11-00318.1

LUCATTO, L. G.; TALAMONI, J. L. B. A construção coletiva interdisciplinar em educação ambiental no ensino médio: a microbacia hidrográfica do Ribeirão dos Peixes como tema gerador. Ciência \& Educação, v. 13, n. 3, p. 389-398, 2007. https://doi.org/10.1590/S1516-73132007000300008

MORIN, E. Os setes saberes necessários: educação do futuro. São Paulo: O Cortez; Brasília, UNESCO, 2006.

QUEIROZ, T. V.; DORNFELD, C. B. Educação ambiental e bacias hidrográficas no contexto escolar. Revista Exitus, v. 9, n. 5, p. 421 - 447, Edição Especial 2019.

ROCHA; T. S. Conscientização ecológica, game studies e Lei 9795/99: A busca de valores ambientais através de jogos eletrônicos de educação para a sustentabilidade. Jus.com.br, 2019.

RODRIGUES, M. E. G. Educação Ambiental: Trabalhando o Uso Racional de Água nas Séries Iniciais. 2010. 54f. Monografia (Especialização em Educação Ambiental) UFSM, Universidade de Santa Maria, RS, Brasil, 2010.

ROLOFF, E. M. A importância do lúdico em sala de aula. In: SEMANA DE LETRAS, 10., 2010, Porto Alegre. Anais eletrônicos[...] Porto Alegre: PUCRS, 2010. Available at: http://editora.pucrs.br/anais/Xsemanadeletras/comunicacoes/Eleana-MargareteRoloff.pdf. Access: 13 Oct. 2019.

SANTOS, G. E. O. Cálculo amostral: calculadora on-line. il. 2011. Available at: http://www.calculoamostral.vai.la. Access: 05 No. 2018.

SCATENA, L. M. Ações em educação ambiental; análise multivariada da percepção ambiental de diferentes grupos sociais como instrumentos de apoio a gestão de pequenas bacias-estudo de caso da microbacia do córrego da Capituva, Macedônia, SP. 2005. Tese (Doutorado) - Universidade de São Paulo, São Paulo, 2005.

SCHIEL, D. et al. O estudo de bacias hidrográficas: uma estratégia para educação ambiental. São Carlos: Rima, 2002.

SHEPARDSON, D. P. et al. What is a Watershed? Implications of Student Conceptions for Environmental Science Education and the National Science Education Standards. Science Education, v. 91, p. 574-578, 2007. https://doi.org/10.1002/sce.20206

SILVA, A. M. Princípios Básicos de Hidrologia. Lavras: Departamento de Engenharia. UFLA. 1995. 
TAJRA, S. M. Informática na Educação. São Paulo: Érica, 2000.

TARGA, S. M. et al. Projeto Educa-Ação-Água. Taubaté: UNITAU, 2017. Available at: http://ipabhi.org/educa-acao-agua-unitau/jogo/materiais/manual_prof_ef2.pdf. Access: 20 Apr. 2018.

TAUBATÉ. Secretaria da Educação. Consolidado baseado nos dados da Secretaria Escolar Digital - SED. Taubaté, 2019.

WORDCLOUDS.COM. Webpage. Available at: https://www.wordclouds.com. Access: 23 June 2019. 